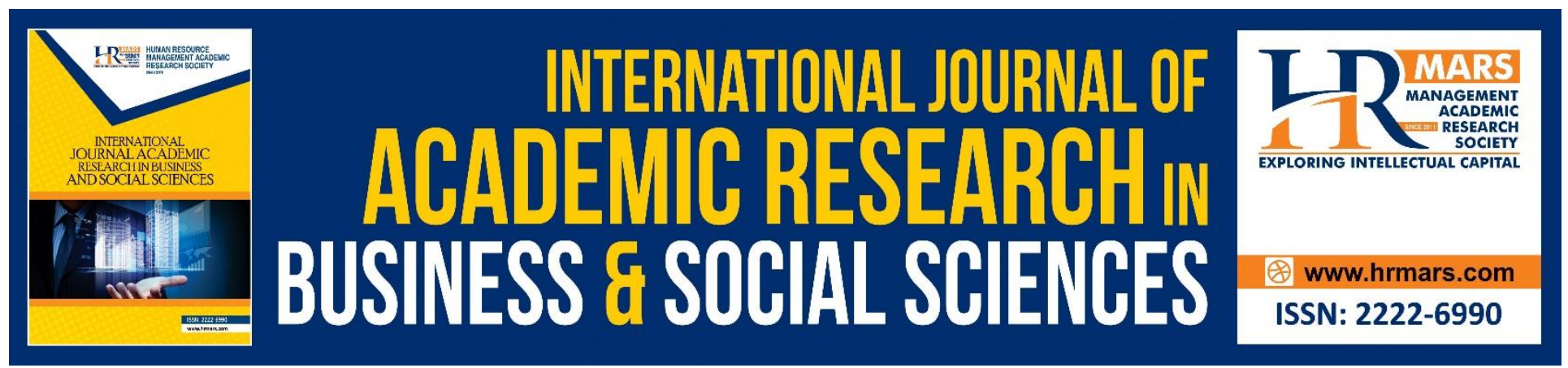

\title{
Breastfeeding and Career Care: Is there any Conflict of Interest? An Islamic Perspective
}

M.H. Islam, ASM Shahabuddin, Fadzli Adam, M. M. Rahman, Rebeka Sultana

To Link this Article: http://dx.doi.org/10.6007/IJARBSS/v8-i11/4965

DOI: $10.6007 /$ IJARBSS/v8-i11/4965

Received: 13 Oct 2018, Revised: 30 Oct 2018, Accepted: 26 Nov 2018

Published Online: 30 Nov 2018

In-Text Citation: (Islam, Shahabuddin, Adam, Rahman, \& Sultana, 2018)

To Cite this Article: Islam, M. H., Shahabuddin, A. S. M., Adam, F., Rahman, M. M., \& Sultana, R. (2018).

Breastfeeding and Career Care: Is there any Conflict of Interest? An Islamic Perspective. International Journal of Academic Research in Business and Social Sciences, 8(11), 885-893.

Copyright: (c) 2018 The Author(s)

Published by Human Resource Management Academic Research Society (www.hrmars.com)

This article is published under the Creative Commons Attribution (CC BY 4.0) license. Anyone may reproduce, distribute, translate and create derivative works of this article (for both commercial and non-commercial purposes), subject to full attribution to the original publication and authors. The full terms of this license may be seen

at: http://creativecommons.org/licences/by/4.0/legalcode

Vol. 8, No. 11, 2018, Pg. 885 - 893

http://hrmars.com/index.php/pages/detail/IJARBSS

JOURNAL HOMEPAGE

Full Terms \& Conditions of access and use can be found at http://hrmars.com/index.php/pages/detail/publication-ethics 


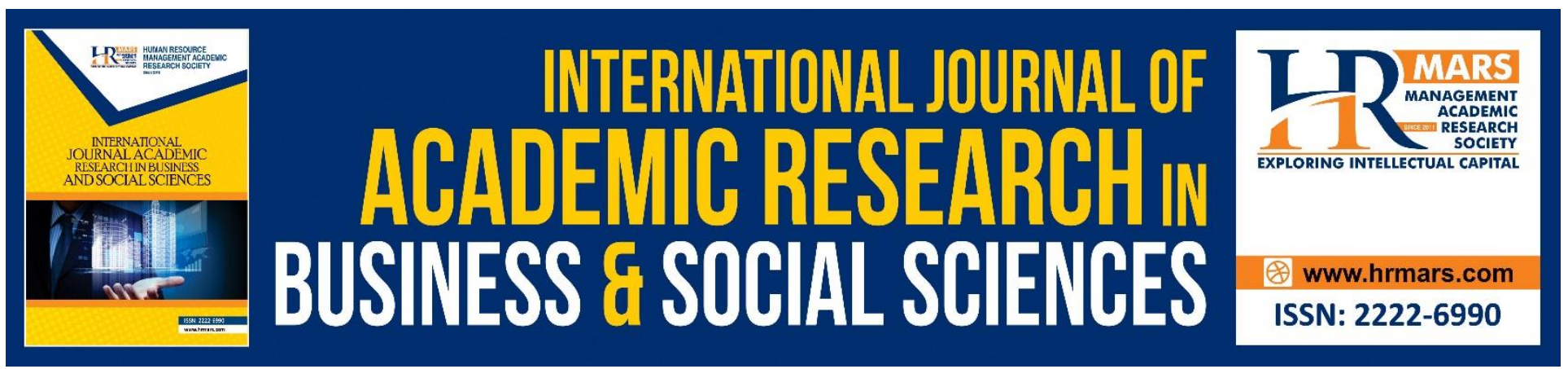

\title{
Breastfeeding and Career Care: Is there any Conflict of Interest? An Islamic Perspective
}

\author{
M.H. Islam¹, ASM Shahabuddin², Fadzli Adam³ ${ }^{3}$ M. M. Rahman4, \\ Rebeka Sultana ${ }^{5}$ \\ ${ }^{1}$ Research Institute for Islamic Product and Civilization (INSPIRE) \\ ${ }^{2}$ Department of Business Administration, Uttara University, Dhaka-1230, Bangladesh \\ ${ }^{3}$ Research Institute for Islamic Product and Civilization (INSPIRE) \\ ${ }^{4}$ Institute for Community Development and Quality of Life (iCODE) \\ 1,3,4 University Sultan Zainal Abidin, Gong Badak Campus, 21300, Terengganu, Malaysia \\ ${ }^{5} \mathrm{PhD}$ in Information System, International Islamic University Malaysia (IIUM) \\ Email:mhedayatul@unisza.edu.my
}

\begin{abstract}
While a breastfeeding mother is at work, her child below two years (i.e. infant) is deprived of direct care and breastfeeding. This holds for almost one-third of the day when a mother works outside of the home. In her absence, the child is bottle-fed by a childcare center or a home-maid or a relative. These ways of rearing a child have been largely accepted in the modern society. The concept that provided the foundation for this acceptance is right to work by every adult member of the society. This paper deals with the conflicts between a child's privilege to breastfeeding and a mother's right-to-work from an Islamic perspective. Without submitting to the overwhelming phenomenon of working couples in the contemporary society, this paper gives priority to the child's privilege to personal care and breastfeeding over the mother's right-to-work. Hence, it is argued that a working mother who willfully suspends her work during breastfeeding period is successful in achieving a balance between her role as suckling mother and her concern for her career development. This prioritizing of childcare has been grounded in and supported by the framework of Wasatiyah Paradigm and Maqasid al Shari'ah.
\end{abstract}

Keywords: Breastfeeding, Childcare, Career Care, Wasatiyah (Balanced Approach) and Maqasid al Shari'ah (Objectives of Shari'ah)

\section{Introduction}

Working parents with young children resort to childcare centers or maids to ensure their children's care while they are at work. Primarily motivated by pecuniary interests, maids and childcare centers act as substitute caregivers by rendering children the services they are paid for. The children who grow in the laps of the substitute caregivers are substantially deprived of their mothers' spontaneous 
INTERNATIONAL JOURNAL OF ACADEMIC RESEARCH IN BUSINESS AND SOCIAL SCIENCES

Vol. 8, No. 11, Nov, 2018, E-ISSN: 2222-6990 @ 2018 HRMARS

loving care. Could this deprivation be tantamount to violation of child right? Does mother's right-towork stand at odd with her child right-to-breastfeeding? The purpose of this paper is to articulate these questions and look for a balance between the conflicting interests of childcare and career care from an Islamic perspective.

\section{Breastfeeding Benefits for Children}

It is projected that breastfeeding saves about millions of children's lives annually from common infectious diseases (Labbok, 2006). More interestingly the Lancet Child Survival Series estimates that 1.3 million additional lives could be saved yearly if women were enabled to achieve 6 months exclusive breastfeeding with continued breastfeeding thereafter (Jones et al., 2003). It is traditionally well-established that only breastfeeding, and breastfeeding alone without other foods or liquids, provides the ideal nourishment for infants for the first six months of life (Labbok, 2006). Breast-milk contains the nutrition which a child needs, including the proportion and suitability for its body for digestion and absorption. The various nutritional elements are not static. They change daily, according to the infant's needs (Buckley, 2009). A baby has a special formula prepared in his mother's breast to make it a suitable diet. The Gracious and Bountiful God divinely provides the mammary glands with the know-how to adjust its secretions according to the variable and changing needs of the growing infant (Hamid and Az'oz, n.d). Likewise, the modern medical science has also strongly recommended the advantages of prolonged breast-feeding. One recent study (Jaafar et al., 2016) has shown that breast-fed infants may not need complementary or supplementary feeding during the first nine to 12 months.

One of the many benefits from breastfeeding during the first year of an infant's life is the effect on long-term cognitive development and IQ. In a longitudinal study of neurodevelopmental evaluation from Poland, Jedrychowski et al. (2012) assessed 468 infants of non-smoking women over five different time points: at 1, 2, 3, 6, and 7 years of age. Infants who were exclusively breastfed consistently demonstrated between 2.1 and 3.8 higher IQ points at each measurement session compared with those who received mixed feeding (human milk plus infant formula). The longer the duration of exclusivity of breastfeeding, the higher was the IQ benefit. In this and similar studies, (Chung et al., 2007; Kramer et al., 2008; Jedrychowski et al., 2012; Michaelsen et al., 2009) the overall IQ advantage from breastfeeding appear to be small, but the effect size is highly significant from a public health perspective. Improvements of even a few IQ points, especially at the lower end of the IQ distribution, will reduce the number of children who might otherwise need special education (Michaelsen et al., 2009).

Brion et al. (2011) took a different approach to study the causal relationship between breastfeeding and cognitive outcomes. They compared two cohorts: one from a high-income country, the British Avon Longitudinal Study of Parents and Children (ALSPAC), with a sample size of about 5,000 children, and another from a low- and middle-income country, the Brazilian Pelotas cohort, with a sample size of about 1,000 children. Using novel analytical methods to establish causal inferences, the study found beneficial effects of breastfeeding on children's blood pressure and body mass index only in the ALSPAC cohort, whereas there was a robust positive effect of breastfeeding on children's IQ in both cohorts. Such differential effects of breastfeeding on blood pressure and body mass index were 
INTERNATIONAL JOURNAL OF ACADEMIC RESEARCH IN BUSINESS AND SOCIAL SCIENCES

Vol. 8, No. 11, Nov, 2018, E-ISSN: 2222-6990 C 2018 HRMARS

perhaps due to residual confounding, whereas the consistent positive association of IQ in both populations suggested a causal biological effect.

\section{Right of Infant to Breastfeeding from an Islamic Perspective}

Islam encourages mothers to nurse their babies for prolonged periods (up to two years). Meanwhile, Islamic teachings allow freedom for the lactating mother from other heavy responsibilities. This provision holds even if she is divorced (Al-Bar, 1986). She is absolved from any other bondage in order to give her full time and care to her baby. The implications of the Islamic teachings for a sound physical and mental growth are quite fundamental.

Allah (SWT) has deliberately commanded nursing and breastfeeding of the infant primarily depending on the physical condition of the mother. In the Qur'an:

"Mothers (should) suckle their children for two full years, for one who wants to complete the (period of) suckling. It is the obligation of the one to whom the child belongs that he provides food and clothing for them (the mothers) with fairness. Nobody is obligated beyond his capacity. No mother shall be made to suffer on account of her child, nor the man to whom the child belongs, on account of his child. Likewise responsibility (of suckling) lies on the (one who may become an) heir (of the child). Now, if they want to wean, with mutual consent and consultation, there is no sin on them. And If you want to get your children suckled (by a wetnurse), there is no sin on you when you pay-off what you are to give with fairness, and fear Allah, and be assured that Allah is watchful of what you do." (Al-Baqarah 2: 233)

The sense of obligation in nursing and suckling is that mother, however, should not be forced to suckle, if she has valid excuse. Similarly, the father too, should not be forced to hire a wetnurse if he is unable to do so, and the mother is able to suckle. Moreover, if the father of the child dies, the liability of the expenses of suckling lies on the guardian of the child who may become an heir of the child if the child dies. Reference to his being heir of the child is to indicate that benefits are always tied up with obligations. The one who gets benefits also bear some liabilities (Usmani, 1998).

The following Qur'anic verses have also synchronized the same attitude of mother and child relationship. Allah (SWT) said:

"We commanded man (to be good) in respect of his parents. His mother carried him (in her womb) despite weakness upon weakness, and his weaning is in two years. (We said to man,) "Be grateful to Me, and to your parents. To Me is the ultimate return." (Qur'an 31:14). "And We have enjoined upon man to do good to his parents. His mother carried him with difficulty and delivered him with difficulty. And his carrying and his weaning is (in) thirty months, ${ }^{1}$ until when he attains his

\footnotetext{
${ }^{1}$ These thirty months include minimum period of pregnancy that is six months and the maximum period of suckling a child, that is, two years.
} 
maturity and reaches forty years, he says, "My Lord, grant me that I offer gratitude for the favor You have bestowed upon me and upon my parents, and that I do righteous deeds that You like. And set righteousness, for my sake, in my progeny. Of course, I repent to you, and truly I am one of those who submit to You." (Qur'an 46:15)

Even though mother is obliged to do breastfeeding as it is the right of infant, the divorced and widow has also been instructed in this respect. The Qur'an emphasised upon the widow. "Provide to them (the divorced women) residence where you reside according to your means, and do not hurt them to straiten (life) for them. And if they are pregnant, spend on them till they give birth to their child. Then if they suckle the child for you, give them their fees, and consult each other (for determining the fee) with fairness, and if you create a deadlock between you, then another woman will suckle him". "A man of vast means should spend according to his vast means. And anyone whose sustenance is limited should spend from whatever Allah has given to him. Allah makes no one liable beyond what He has given to him. Allah will soon bring ease after a difficulty." (Qur'an 65: 6, 7)

From these verses, the following points regarding the "nursing of the child" were constructively underlined. Mothers are encouraged to nurse their babies for a period varying from 6 to 24 months. Even if the mother is divorced, she should be supported in her nursing of her child for that period. ${ }^{2}$ The father should pay her cost of living as she will be fully occupied by nursing his offspring (Hamid \& $\left.A z^{\prime} O z, n . d\right)$.

If the parents are separated or divorced they should frequently counsel each other for the sake of the child's future. If it is decided that the mother cannot nurse the baby (for example, if she lacks milk in her breasts), then a wet nurse must be asked to help. The true father should pay the foster mother recompense (Al-Bar, 1986).

The Islamic communities paid great attention to breastfeeding and wet nurses were very common until recently. Even if the mother nurses her baby it is not uncommon for a neighbor, relative or friend to breastfeed the newcomer. Extended families also have the advantage of relieving the burden on young mothers (Jaafar et al., 2016; Al-Bar, 1986). The holy Qur'an has stressed the importance of commonly accepted period of breast-feeding for two years. Ibn Hazm (994-1064), an Andalusian Islamic philosopher and jurist opined, "A mother should nurse her baby even if she was the daughter of the king. She is not exempted from that duty, unless she is incapable of nursing." The nursing mother should be financially supported by the husband, even if she is divorced. If the father dies, his

\footnotetext{
${ }^{2}$ Although the divorcee women have the right of maintenance during the period of 'Iddah, one may feel if the period is prolonged because of pregnancy, he is not obliged to maintain the divorcee for a such long period. The verse removes this misconception and says that even the entire period of pregnancy; the divorcees are entitled to receive maintenance from their husbands who have divorced them.
} 
INTERNATIONAL JOURNAL OF ACADEMIC RESEARCH IN BUSINESS AND SOCIAL SCIENCES Vol. 8, No. 11, Nov, 2018, E-ISSN: 2222-6990 @ 2018 HRMARS

heirs should support her fully during lactation. If there is no heir, the government takes responsibility. If Islamic teachings are adhered to many evils that befall children and their mothers could be avoided.

\section{Right-to-Work and Conflict of Interests}

"Workforce 2000" report, the U.S. Department of Labor, documented the significant changes taking place in family structures that are clearly in evidence today (Johnston \& Packer, 1987). The following points are worthy noted; a) Just few decades back, a typical household included an employed father and an unemployed mother, whereas today, such households are relatively rare, comprising less than $15 \%$ of all U.S. households. b) With the emergence of the working family, according to Powell and Graves (2003), between $63 \%$ and $81 \%$ of women in the workforce were mothers with children in 1970s and 1980s. c) Once the working family extended, a burgeoning of needs related to childcare and other family responsibilities, such as caring for elderly parents and relatives. Along with these changes to families, the work environment has also become more demanding because of high income. Many men and women have begun to working longer hours. They are experiencing more conflicts between their work and family roles. These conflicts are the contributory factors to a working-family feud, lower job satisfaction, increased stress, employee turnover, and decreased productivity (Granrose et al, 1992). In this dichotomy breastfeeding is an area where one might perceive a potential for conflict between the woman's and child's right (Johnson, n.d.).

\section{Reconciliation of Conflicting Interests}

The sense of right and justice, and the balance between the rights of an infant and a mother uphill the "Wasatiyah (Balanced) paradigm". The spirit of Wasatiyah (Balanced approach) in the Qur'an embraces three fundamental elements; justice, steadiness, and excellence. To transmit the justice for an infant obviously endorses the breastfeeding and rearing rights. Conversely, the Quran also acknowledge the right of women to work in the workforce in particular circumstances. The sense and right of justice here for a mother demanding the necessity of working if none of the family member is incapable of earning/doing work (Khan, N.A., 2018). To reconcile the conflict of interest, i.e., role of a breastfeeding mother and her right to work, henceforth, Islam assert to prove her natural and divine potential maternity. Ever since, she is a 'mother' and 'pillar' of an infant on the one, and also a 'tower' of a human society on the other.

Considerably, one of the most important milestones of social justice in Islam, as mentioned by alQaradawi (2010), towards mother and infant is to establish justice and respect. Justice for mother, respecting her and taking care of her nature, as well as affirming the rights, prestige, and dignity. Islam has given her and making her free from the sediment of the ages of backwardness and Islamic fall-back which brought woman from her nature and did not take care of her feminity.

Furthermore, a good society needs honesty and justice to uphold a healthy and prosperous family and the social order. To maintain the standard of the family and the social order, it would come only from the sincere members of the society especially from mother and child who have patience and appreciate others (Moten, 2002). In this regard, al-Qaradawi (1993) advised: Take care of the family which is the foundation for community, and the mother and her new born baby is the primary pillar 
to build up a good society. It is the responsibility of the Muslim society to protect woman from the obsolete customs of the East as well as from the encroaching traditions of the West that aims to strip them off their true identity. The perspective of the justly balanced (al-Wasatiyah) worldview is inspired partly by the following verse of the Qur'an (9:71): “The believers, men and women, are protectors of the one another. They enjoy what is right and forbid what is wrong.

Likewise, Maqasid al Sharia'h (Objectives of Sharia'h /Islamic Law) aims at the attainment of good, welfare, benefits, and warding off evil, injury, loss, etc. for the creatures. Moreover, Shari'ah aims at the welfare of the people in this life and life in the hereafter. For this purpose it has advised people to adopt such means and measures that may give advantage/benefit/well-being to them and may ward off evil/injury/loss from them (Fauziah, 2014). Notwithstanding, one of the very important objective of Shari'ah is Rahmah (mercy or Compassion), that seek to eliminate prejudice, alleviate hardship and establish justice. The laws of the Qur'an and Sunnah also seek to promote co-operation and support within the family and the society at large. 'AdP or Qist (Justice), is indeed a manifestation of Allah's Mercy, but may also be seen as a principal of the Shari'ah. The objective of Rahmah is most clearly manifested in the realization of Maslahah (Benefit) in everyday family life (Kamali, 2008).

Furthermore, Imam Shatibi's "Five Objectives of Shari'ah" (Maqasid al-Shari'ah) comprise these objectives: Dharuriyat (Necessity), Hajiyat (Requirement) and Tahsiniyat (Embellishment) of Human being. Of these three the most essential components of Dharuriyat (Necessity) includes (i) Deen (protection of faith); (ii) Nafs (protection of life); (iii) Nasl (protection of posterity); (iv) Maal (protection of property); (v) Aql (protection of reason).

Hifdh al Nasl (protection of progeny) is the third purpose of Maqasid al Shari'ah. It upholds the divine justice and right towards an infant and mother guaranteed by Islam. The necessity of mankind to protect the "Nasl" (Progeny), the right of infant favourably given the priority over mother's right to work. Hence the family in general and mother in particular contributes to the fulfillment of this function by making sure that children are cared for well so that they grow into healthy adults who can bear children. It is naturally meaningful to understand the broad outline of the objectives of the Shari'ah in the first place before one tries to move on to specifics (Fauziah, 2014). Moreover, the protection of posterity i.e. 'Nasl' is only related to caring and rearing of children for current as well as future generation. Here comes the role of mother as mother-cum-child rearing of a family.

\section{Conclusion}

Islam gives each family member an important role to play whenever the new member (baby) of the family is born. So, fathers and mothers take care of the children and give them the best Islamic upbringing. As argued, here comes the role of parents and most particularly the mother to impart in their babies the heteronomy values based on respect obedience and loyalty. Mother together with the father cannot rely on anybody else in this world to impart these most important core values in the very beginning of their babies' lives. This is also the period during which a mother can teach her babies how to cope with a simple lifestyle based on moderation rather than a luxury. The pursuit of a moderate, as opposed to affluent lifestyle, warrants a continuous practice in the day to day life. This is manifested through the entire attitude towards life in this material world and the world

\footnotetext{
3 'Adl-literally meaning to place things in their right place.
} 
hereafter. Hence this paper strongly argues that only a mother with multiple roles as prescribed by Islam as one of the three revealed religions ${ }^{4}$ can be entrusted with the most sacred role of building the future generation. However, it is highly warranted that a mother being in the roles of paymaster, childcare, housekeeper, among others, needs to be morally obligated to strike a balance between material and non-material gains. As for the core values, based on balance approach (moderation), it is well-recognized that these does not exist any contradiction among the three revealed religions such as Judaism, Christianity and Islam.

It is worth mentioning that when the breastfeeding and career-care meet up with the conflict of interest in the contemporary Muslim societies. Surprisingly, the western civilized world and very particularly both the United States and the European Union have developed the new blueprints, health care workers. It also outlines the public policy needs and encourages community and health system actions towards pregnant employees and their child-rearing years. In addition, the right to time off for antenatal care and all female employees qualify for a minimum of 52 weeks Maternity Leave with pay which ensures the breastfeeding and take caring of mother to her newborn child. According to Esther Lejbovitz (2017), "Juggling career and family is adoable...but children have to be a priority".

The conflict of interest - breastfeeding (rights of an infant) and career care (rights of a mother to work) is the crucial argument to balance both rights aligns the Wasatiyah landmarks and Maqasid al Shari'ah framework. To uphold the divine justice and right towards an infant and mother guaranteed by Islam and the necessity of mankind to protect the "Nasl" (Progeny), the right of infant favourably given the priority over mother's right to work. In this status quo, a mother can only work when the following circumstances are made. a) Maternity Leave with paid at least for 9 to 12 months to maximum two years. b) Hiring "Wet-nurse or Foster-mother" if the mother has valid excuse to give off breastfeeding. c) Available childcare at the working place. To implement the aforementioned suggestions, the various stakeholders, i.e., state, government, company, NGO in general and family, in particular, can play a significant role in order to make awareness of breastfeeding of newborn baby who is the micro-organization of human society.

\section{References}

Al-Bar, M.A. (1986). Breast Feeding and Islamic Teaching. Jeddah, KSA

Al-Qaradawi, Yusuf (1993). Malamih al-Mujtami' al-Muslim (Features of Muslim Society). Cairo: Maktabah Wahabah.

Al-Qaradawi, Yusuf (2010). Fiqh al-Wasatiyah al-Islamiyyah wa al-Tajdid: Maalim wa Manraatt, Cairo: Dar al-Shuruq.

Brion, M. J. A., Lawlor, D. A., Matijasevich, A., Horta, B., Anselmi, L., Araújo, C. L., ... \& Smith, G. D. (2011). What are the causal effects of breastfeeding on IQ, obesity and blood pressure? Evidence from comparing high-income with middle-income cohorts. International journal of epidemiology, 40(3), 670-680.

\footnotetext{
4 Three "Revealed Religions" also known as "Abrahamic Faiths". They are: Judaism, Christianity and Islam
} 
INTERNATIONAL JOURNAL OF ACADEMIC RESEARCH IN BUSINESS AND SOCIAL SCIENCES

Vol. 8, No. 11, Nov, 2018, E-ISSN: 2222-6990 @ 2018 HRMARS

Buckley. S (2009). Gentle Birth, Gentle Mothering: A Doctor's Guide to Natural Childbirth and Gentle Early Parenting Choices, Celestial Arst, Berkeley, Toronto.

Chung, M., Raman, G., Chew, P., Magula, N., Trikalinos, T., \& Lau, J. (2007). Breastfeeding and maternal and infant health outcomes in developed countries. Evid Technol Asses (Full Rep), 153(153), 1-186.

Esther, L. (2017). Striking a Balance: Work \& Family. Jewish Action, Orthodox Union. Available at: https://jewishaction.com/family/striking-a-balance-work-family/

Fauziah, M. N. (2014) 'Maqasid as shariah', Available at https://www.slideshare.net/fauziahuia/maqasid-as-shariah

Granrose, C. S., Parasuraman, S., \& Greenhaus, J. H. (1992). A proposed model of support provided by two-earner couples. Human Relations, 45(12), 1367-1393.

Hamid, A and Az'Oz, A (n.d). With medicine in the Holy Qur'an. The administration of Qur'an science, Damascus.

Jaafar, S.H., Ho, J. J., Jahanfar, S., Angolkar, M. (2016) Effect of restricted pacifier use in breastfeeding term infantsfor increasing duration of breastfeeding, Cochrane Database of Systematic Reviews, Issue 8. Art. No.: CD007202. DOI: 10.1002/14651858.CD007202.pub4

Jedrychowski, W., Perera, F., Jankowski, J., Butscher, M., Mroz, E., Flak, E., ... \& Sowa, A. (2012). Effect of exclusive breastfeeding on the development of children's cognitive function in the Krakow prospective birth cohort study. European journal of pediatrics, 171(1), 151-158.

Johnson, M. (n.d.) How can the tentions between women's rights and children's right be solved? Something to think about. UNISEF New York, Bulletin, vol. 32.

Johnston, W. B and Packer, A. E. (1987) Workforce 2000: Work and Workers for the Twenty-First Century, Hudson Institute, Indianapolis, Indiana.

Jones G, Steketee R, Black R, Bhutta Z, Morris S, (2003). Bellagio Child Survival Study Group. How many child deaths can we prevent this year? Child Survival II.

Kamali, M. H. (2008). Shari'ah law: an introduction. Oneworld Publications.

Khan, N.A. (2018). Adulthood Of Musa A.S - Forging A Hero Part 3. Available at: https://www.youtube.com/watch?v=mIXD2Y2dcmQ\&index=2\&list=RDKUMaTdEV3y4

Kramer, M. S., Aboud, F., Mironova, E., Vanilovich, I., Platt, R. W., Matush, L., ... \& Collet, J. P. (2008). Breastfeeding and child cognitive development: new evidence from a large randomized trial. Archives of general psychiatry, 65(5), 578-584.

Labbok, M. (2006). Breastfeeding: A woman's reproductive right. International Journal of Gynecology and Obstetrics

Michaelsen, K. F., Lauritzen, L., \& Mortensen, E. L. (2009). Effects of breast-feeding on cognitive function. In Breast-feeding: early influences on later health (pp. 199-215). Springer, Dordrecht.

Moten, A.R. (2002). Revolution to Revolution: Jamat -e-Islami in the Politics of Pakistan (Kuala Lumpur: Islamic Book trust, Kuala Lumpur \& International Islamic University Malaysia Powell, G. N. and Graves, L.M (2003). Women and Men in Management, SAGE publications.

The Holy Qur'an (1979). Translation of verses is heavily based on A. Yusuf Ali's translation, The Glorious Qur'an, text translation, and Commentary, The American Trust Publication.

Usmani, T. (1998). English Commentary of the Qur'an in verse 233 of Surah al Baqarah. 